\title{
WestVirginiaUniversity
}

THE RESEARCH REPOSITORY @ WVU

West Virginia Agricultural and Forestry Experiment

Davis College of Agriculture, Natural Resources

Station Bulletins

And Design

$1-1-1891$

\section{Preliminary investigation of insect ravages : yellow locust}

\author{
A. D. Hopkins
}

Follow this and additional works at: https://researchrepository.wvu.edu/ wv_agricultural_and_forestry_experiment_station_bulletins

\section{Digital Commons Citation}

Hopkins, A. D., "Preliminary investigation of insect ravages : yellow locust" (1891). West Virginia Agricultural and Forestry Experiment Station Bulletins. 16.

https://researchrepository.wvu.edu/wv_agricultural_and_forestry_experiment_station_bulletins/16 @ WVU. It has been accepted for inclusion in West Virginia Agricultural and Forestry Experiment Station Bulletins by an authorized administrator of The Research Repository @ WVU. For more information, please contact ian.harmon@mail.wvu.edu. 
West Virginia University Libraries

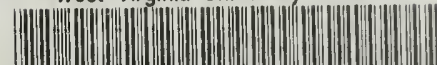

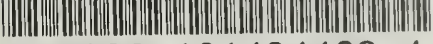
308021014944681 



$$
\text { Bulletin No. } 16 .
$$

\section{WHSI VIRGINIA}

\section{Agricultural Fixperiment Station}

MORGANTOWN, W. VA.

\section{PRELIMINARY INVESTIGATION OF INSECT RAVAGES.}

\section{YELLOW LOCUST.}

A. D. HOPKINS.

ENTOMOLOGIST.

JOHN A. MXERS, 12月. 1"

Director

APRIL, I89I.

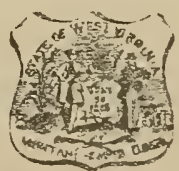




\section{BOARD OF REGENTS OF THE WEST VIRGINIA UNIVERSITY.}

\begin{tabular}{|c|c|c|}
\hline Districe. & Name of Regent. & P. O. Address. \\
\hline I. & J. B. SOMMERVILLE, & Wheeling. \\
\hline 2. & CLARENCE L. SMITH, & Fairmont. \\
\hline 3. & PEREGRIN HAYES, & Glenville. \\
\hline 4. & D. D. JOHNSON, & Long Reach. \\
\hline 5. & JOHNG. SCHILLING, & Spencer. \\
\hline 6. & EDWARD A. BENNETT, & Huntington. \\
\hline 7. & WIRT A. FRENCH, & Princeton. \\
\hline 8. & M. J. KESTER, & Union. \\
\hline 9. & J. F. BROWN, & Charleston. \\
\hline IO. & THOS. J. FARNSWORTH, & Buckhannon. \\
\hline I. & JOSEPH MORELAND, & Morgantown. \\
\hline $\begin{array}{l}\text { I } 2 . \\
\text { I } 3 .\end{array}$ & $\begin{array}{l}\text { JOHN A. ROBINSON, } \\
\text { DR. W. W. BROWN, }\end{array}$ & $\begin{array}{l}\text { Patterson's I } \\
\text { Kabletown. }\end{array}$ \\
\hline
\end{tabular}

\section{MEMBERS OF THE STATION COMMITTEE,}

IOHN A. ROBINSON, JOSEPH MORELAND, DR. W. W. BROWN.
JOHN G. SCHILLING, THOS. J. FARNSWORTH,

President of the University.

TREASURER.

E. M. TURNER, LL. D., . JOHN I. HARVEY.

STATION STAFE.

JOHN A. MYERS, PH. D.,

CHAS. F. MILLSPAUGH, M. D., Botanist and Microscopist. A. D. HOPKINS, Sp'l Agt. Entomology. D. D. JOHNSON, A. M., Agriculturist. RUDOLPH J. J. I)E ROODE, PH. D., Chemist SUSIE V. MAYERS, : - Stenographer and Book-keeper. 
FOREST AND SHADE TREE INSECTS-I.

\author{
Yellow Locust, (Robinia Fseudacacia, L.)
}

Preliminary Investigation of Insect Ravages.

Returning to the Station on August 7 th, after an absence of about two months, I observed the locust trees all along the Baltimore \& Ohio R. R., becween Central Station and Morgantown peculiarly affected. The trees everywhere in the forest and field having a scorched and dead appearance.

The landscape thus marred by the dead appearance of this, one of our most valuable as well as beautiful forest and shade trees, attracted the attention of every one, and excited their wonder and curiosity as to the cause of the trouble.

Arriving at Morgantown, which seemed to be the worst affected district, I at once, by the request of the Director of the Station commenced an investigation which was continued until August I4, when I was called away to attend to other duties. This short time only enabled me to lay a foundation for a future and more thorough investigation, which the extent and increasing value of the locust timber certainly warrants, when it may be destroyed by insects within a few years, as has been done in New England and the West.

The present trouble was found to be caused by insects; and the region thus affected so far as I have since observed extends through Doddridge, Harrison and Preston Counties, from Grafton westward to near the Wetzel County line, from Fairmont through Monongalia County to the Pennsylvania line, and from Piedmont southward through Tucker, Randolph, Upshur and Lewis Counties. The trees were unaffected through Ritchie and Wood Counties, and along the Ohio River as far as was observed, the leaves being fresh and green at the time they seemed to be dying in the infested districts mentioned. This dead and scorched appearance of the locust trees at a time of year when they are noted for their beautiful green foliage was, as far as can at present be learned, first noticed in Harrison County about the year I 885 , when a few scattering trees were observed to turn brown. The number of trees thus affected rapidly increased each year until every tree, bush, and sprout of this species looked as if it had been killed by fire. This trouble continued to spread until at present at least one-fifth of the State is affected.

While over forty species of insects were found to be feeding on different parts of the affected trees, one species, the Locust Hispa, appeared to be the principal cause of the trouble. The following is an account of this and other insects so far observed. 


\section{EXPLANATION OF PLATE.}

\section{LOCUST TREE INSECTS.}

Fig. I. Locust Hispa, Odontota Dorsalis.
a. Under side of foot showing peculiar formation.
b. Profile of foot showing peculiar formation.
c. Supposed egg case.
d. Longitudinal section of "c."
e. Larva of Fig. I.
f. Pupa of Fig. I.

Fig. 2. Odontota nervosa.

Fig. 3. Locust Borer, Clytus robinae. 
PLAIt I's

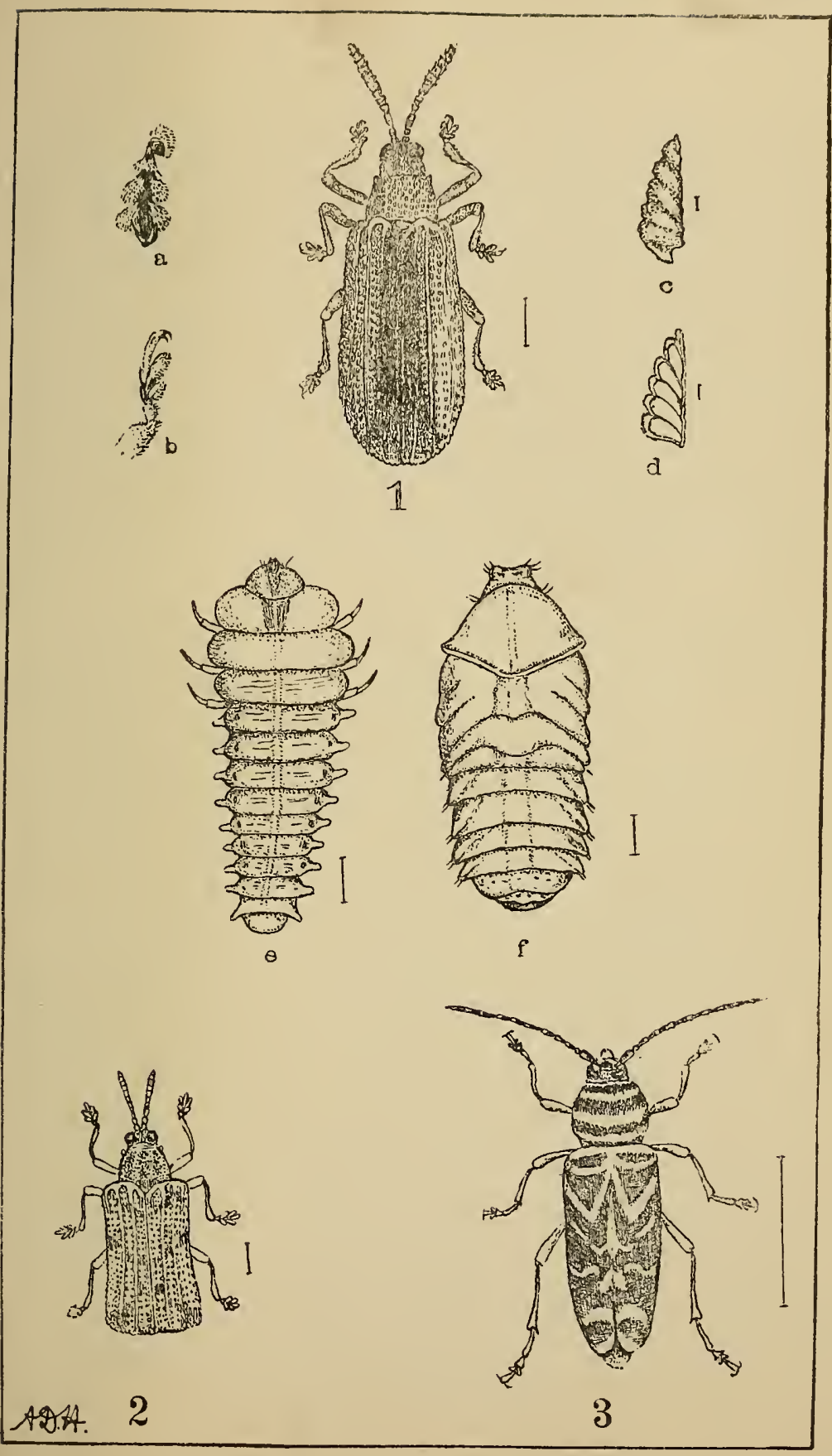

IOOUST TREF INSEOTS. 
Digitized by the Internet Archive in 2010 with funding from

Lyrasis Members and Sloan Foundation 
TME. LOCUST HISPA.

(Odontota dorsalis, Oliver.)

This beetle was extremely plentiful on the locust leaves at the time the investigation was being made, as many as eight were frequently found on a single leaf. The beetle is about one-fourth of an inch long, yellowish above with a black head and black stripe along the back. They are rough and ridgy above; but smooth and shining black beneath. They probably appear in May or June when they deposit their eggs on the under side of the leaf, which hatch into small grubs that burrow into the leaves and feed upon the substance beneath the surface; forming blisters near the edges which usually extend to the mid-rib. When these grubs or larvae become full grown, they resemble $e$ Fig. I, as seen in the microscope. They then change within the blister to the pupa form which the beetles soon emerge, and feed on the surface of the remaining unaffected leaves, The blisters formed by the larvæ of this insect, the leaves skeletonized by the beetle, together with the blisters formed by other leaf mining larvæ, cause the leaves to turn brown, wither and fall.

By referring to my notes and collections, I find that this beetle and another belonging to the same genus represented at Fig. 2, were taken feeding on the leaves of the locust, at Morgantown, June Ioth and at Kanawha Station, June r6th.

While this insect has been known to Entomologists for a number of years, and has been frequently reported as doing damage to locust trees in different parts of the country, especially in the Middle States; very little has been written on the subject, at least as far as is at present accessible to me. It is my intention to make a complete study of the habits of this insect the coming summer, and endeavor to find, if possible, a remedy in its parasites and natural enemies.

Like the plum curculio, it is the habit of this beetle to fall to the ground when alarmed, and in the case of valued shade trees, it may be possible to destroy them by the jarring process which is so successful with the curculio. Their habit of feeding on the upper surface of the leaves would make it easy to treat them by spraying the trees with poison liquid. While it may be possible to successfully destroy these insects by jarring and spraying sufficient to preserve the foliage of a few valued shade trees, such a remedy could not be applied to those of the forest and field. This insect alone will probably do no more harm than to mar the beauty of the locust as a shade and forest tree, yet combined with other and more destructive insects found preying upon the trees, may result in a complete destruction of the locust timber, which if so, would cause a loss of not only thousands but millions of dollars to the State. It is therefore of the greatest importance that a thorough investigation should be made of the locust tree insects to find if possible a practical, natural or artificial remedy against their ravages. 
(Onontota nerrosa, Panzer, Fig. 2.)

Found quite plentiful with the locust hispa feeding upon the sur face of the leaf. Nothing further has so far been observed of its habits.

THE LOCUS'T BORER.

(Clytus Robinae, Forster, Fig. 3.)

This beautiful "black velvet and gold beetle" is found feeding on the blossoms of golden rod in September. It deposits its eggs on the branches and trunk of locust trees. The eggs hatch into grubs which bore into the green wood where they feed, and if plentiful often cause the death of the tree. Many trees have been observed in and around Morgantown partly and completely dead, caused evidently by this insect. The grubs were observed early in the season within the green wood and the beetles were found quite frequent on the golden rod in September; but this insect is probably not doing much damage to the locust at present in the region infested by the Hispa.

This beetle according to Harris, Packard and Riley is "by far the most destructive pest of the locust." It "has nearly exterminated the locust in New England" and "nearly all the locust groves in the west have been destroyed by it."

Should this insect, therefore, appear in any great numbers in districts like the one mentioned, where the vitality of the trees would naturally be weakened from the loss of leaves, the locust would certainly be doomed to destruction.

Shade trees could probably be protected from the ravages of this insect by spraying the trunk and branches with a strong solution of soft soap and water during the period in which the beetles deposit their eggs, which is supposed to be between the last we ek in August and the first week in October. Two or three applications during this time would very likely prove successful. This, like the remedy for the Hispa would, however, only be practicable to apply to a few choice shade trees. For a general remedy, we must look as before to the natural enemies of the insect.

THE LOCUST-TREE CARPENTER-MOTH.

\section{(Xyleutes Robinae, Harris.)}

This is a large night flying moth. It deposits its eggs in July on the bark of mature but healthy trees. The worms, according to Dr. Asa Fitch, on hatching from the egg sink themselves inward and feed at first on the soft inner part, until when their jaws acquire more strength, they penetrate to the hard sap wood and finally resort to the solid heart-wood, residing mostly in and around the 
center of the trunk, boring the wood here usually in a longitudinal direction, and moving backwards and forward in their burrows, enlarging them by gnawing their walls as they inerease in size, whereby the excavation comes to present the same diameter through its wole length. He further says that of all the wood-boring insects in our land, this is by far the most pernicious, wounding the trees the most cruelly. It perforates a hole the size of an half-inch auger, or large enough to admit the little finger, and requires three or four years for the bark to close together over it. This hole running inward to the heart of the tree and admitting the water thereto from every shower that passes, causes the decay in the wood to commence, and the tree never regains its previous soundness.

These worms probably live within the burrows in the tree three years before changing to moths. When full grown, they measure from two and one-half to three inches long. They "always attack the living and healthy trees," usually at a point where the large branches are given off. These worms we found quite frequent at Kanawha Station in April in locusts cut for posts and in oak trees cut for wood and lumber, and the large trees recently cut on the University grounds here show evidence of their destructive work. This insect also attacks the Red, White and Black Oaks, and is probably the most injurious forest tree insect known.

To prevent the moths from depositing their eggs, the same remedy as recommended for the locust borer (Clytus Robinae) applied in July or August would probably prove efficient.

\section{THE LOCUST SPROUT AND TWIG BORER.}

This is a little red caterpillar, which bores into the pith of young sprouts and tender branches. A swelling or gall is formed around the pcint of attack, and the sprout or branch usually dies, or breaks off at this point. This lava was found to be very plentiful and destructive in the vicinity of Morgantown, four or five being frequently found in a single sprout or branch.

Very little has so far been learned of the history of this insect; it must, however, leave its burrow and enter the ground to change to the pupa, as I have not been able to find a pupa within the burrow. Between August 7 th and I 4 th and September I 2 th, to October 8th, they were found in the sprouts all sizes, from the very smallest or just hatched up to the mature worms. It is, therefore, possible that there are several broods and that they may become very destructive to young trees if neglected.

To prevent this insect from increasing, the young sprouts affected (which may readily be found by their swelled and knotty appearance), should be cut out and burned while the worms are yet in their burrows.

THE YELLOW LOCUST MIDGE.

(Cecidomyia Robiniae, Haldeman).

This is a minute midge or gnat. It deposits its eggs near the 
margin of the leaf, which hatch into very small maggots. Their irritaton causes the edge of the leaf to thicken and roll up forming a kind of gall where the sap probably collects and furnishes them with food. This insect was found quite as plentiful as the Hispa, nearly every leaf having one or more of these galls on their edges containing both larvæ and pupæ.

This insect is possibly quite as injurious to the locust trees as the Hispa, especially in marring the beauty of the foliage, as they at tack the young and tender leaves and prevent their development. For this insect there seems to be no remedy.

LOCUST LEAF MINERS.

Six undetermined species of larvae were observed mining under the skin of the leaves forming blisters similar to those formed by the Hispa; different species having a preference for certain and different points on the leaf. One species, a small green larvæ, is very abundant at the present time (October 8 th). Nearly every remaining leaf being inhabited by one or more of them in blisters formed on the upper surface over the mid rib. On September I2th, I observed that this species was very plentiful in Wood county, the trees turning brown as they were here in Morgantown in August. The damage to the tree from this species, however, cannot be very great from the fact that they attack the leaves about the natural time for them to fall.

THE LOCUST SKIPPER BUTTERFLY.

\section{(Eudamus Tityrus, Fab.)}

This is a medium size butterfly of rapid flight with a large white or silver spot on the under wing, common in yards and along roadsides during the summer. They deposit their eggs singly on the leaves of the yellow locust, and the cultivated flowering variety, the eggs hatching in a few days into worms, which when young, roll up the edge of the leaves, and as they grow larger fasten two or three leaves together forming a kind of tent in which they remain through the day, coming forth to feed during the night. These worms were found very plentiful on the locust trees here, and the butterfly was found very common wherever the locust grew on our route through the State. Harris says that this worm sometimes strips the leaves from the common yellow and vicid locust trees. Spraying with poison liquids would probably preserve our shade trees from the structive attack of this insect.

\section{LOCUST LEAF ROLLERS AND PASTERS.}

Seven undetermined species were found rolling and pasting the leaves together and feeding on the inner surface of their covering; one or two species being very plentiful. 
By reference to the collection and notes, it is found that seventyeight species of insects were observed and taken on the locust trees during the season, those mentioned above bcing the principal ones doing damagc. Of this number, forty-five species wore found feeding on some part of the trees. It is my intention to continue the investigation of these locust tree insects during the coming summer and until a more complete report can be made. 'The results of which will appear in a future special bulletin. In the meantime, if those receiving this report who are interested in the investigation, will report their observations as to the amount of locust timber and its value in their respective localities or counties, the extent of the danage from injurious insects and such other observations of interest which may from time to time be made, it will aid very materially in making the future bulletin of special value to every one interested in the preservation of this, one of the most valuable timbers in the State. 
